\title{
UPAYA EDUKASI UNTUK BERADAPTASI PADA KEBIJAKAN NEW NORMAL DAN MENINGKATKAN IMUNITAS TUBUH SELAMA PANDEMI COVID-19 MELALUI KEGIATAN SEMINAR ONLINE
}

\section{EDUCATION FOR NEW NORMAL ADAPTATION AND IMPROVING BODY IMMUNITY DURING COVID-19 PANDEMIC THROUGH ONLINE SEMINAR PROCUREMENT}

\author{
Akmal Yusuf Haryadi ${ }^{1}$, Azzahra Novita Dewi ${ }^{2}$, Dannis Pradana ${ }^{2}$, James Ricardo ${ }^{2}$, \\ Mela Salsabilah $^{2}$, Muhammad Ariq Syahputra ${ }^{2}$, Pradipta Arum Faustina ${ }^{2}$, Sindy \\ Nur Erwine Putri' ${ }^{2}$, Tasya Nadia ${ }^{2}$, Tsalsa Fiorentina ${ }^{2}$ \\ ${ }^{1}$ Teknologi Hasil Perikanan, Fakultas Perikanan dan Kelautan, Universitas Airlangga, \\ ${ }^{2}$ Mahasiswa KKN BBM 62 Universitas Airlangga \\ email: akmal.yusuf.haryadi-2017@fpk.unair.ac.id
}

\begin{abstract}
The purpose of the $230 \mathrm{KKN}$ BBM group activity period 62 is to educate and prepare the public in facing and responding to the Covid-19 pandemic. Our method is to create two online seminar sessions, where in the first online seminar session the topic we raised was about "new normal" which aims to let the public know in more detail how and what the rules are in the new normal policy and can prepare themselves to face the policy and not misunderstand about new normal. Then our second online seminar raised the topic "maintaining immunity and dental hygiene" which aims to explain how steps need to be taken to maintain immunity especially during the current COVID-19 pandemic, as well as knowledge about how to care for cleanliness. teeth and mouth. By using the questionnaire attached after the activities of each online seminar it was found that the majority of participants who attended the seminar were more aware of the "new normal" policy and also knew how to increase body immunity during the Covid-19 pandemic. And the majority of participants felt the information obtained was useful and would apply it in everyday life. And we also carry out social activities directly to the community with the target of street vendors, namely by distributing masks and hand sanitizers in the Sungai Bambu area, Tanjung Priok District, North Jakarta while increasing the community to also run and undergo a "new normal" policy.
\end{abstract}

Keywords: Covid-19, new normal, body immunity, dental health, online seminar

abstrak

Tujuan kegiatan kelompok 230 KKN BBM periode 62 adalah untuk mengedukasi dan memperisapkan masyarakat dalam menghadapi dan menanggapi pandemi Covid-19. Metode yang kami lakukan adalah dengan membuat dua sesi seminar online, dimana pada sesi seminar online yang pertama topik yang kami angkat adalah tentang "new normal" yang bertujuan agar masyarakat dapat mengetahui lebih detail bagaimana dan apa saja aturan-aturan yang ada pada kebijakan new normal serta bisa mempersiapkan diri untuk menghadapi kebijakan tersebut dan tidak salah memahami tentang new normal. Lalu seminar online kami yang kedua mengangkat tentang topik "menjaga imunitas tubuh dan kebersihan gigi" yang betujuan untuk menjelaskan bagaimana langkah-langkah yang perlu dilakukan untuk menjaga imunitas tubuh terutama pada saat pandemi COVID-19 saat ini, serta diberikan juga pengetahuan mengenai cara merawat kebersihan gigi dan mulut. Dengan menggunakan kuosioner yang dilampirkan setelah kegiatan masing- masing seminar online didapatkan bahwa mayoritas dari para peserta yang mengikuti seminar lebih mengetahui tentang kebijakan "new normal" serta juga mengetahui cara meningkatkan imunitas tubuh selama pandemic Covid-19. Dan mayoritas peserta merasa informasi yang didaptkan berguna dan akan mengaplikasikanya dalam kehidupan sehari-hari. Serta kami juga melakukan kegiatan sosial secara langsung ke masyarakat dengan target 
pedagang kaki lima, yaitu dengan cara membagikan masker dan hand sanitizer di area Sungai Bambu, Kecamatan Tanjung Priok ,Jakarta Utara sambil mengingkatkan masyrakat untuk juga menjalankan dan menjalani kebijakan "new normal".

Kata kunci : Covid-19, new normal, imunitas tubuh, kesehatan gigi, seminar online

\section{PENDAHULUAN}

Kuliah Kerja Nyata (KKN) yang diselenggarakan oleh pihak Universitas Ailangga merupakan sarana bagi mahasiswa untuk meningkatkan kemampuan bekerjasama, beradu argummen, dan kepemimpinan di setiap individunya. Tak hanya itu, Kuliah Kerja Nyata juga dapat meningkatkan rasa sosial dan kepekaan terhadap masyarakat karena mahasiswa dituntut untuk terjun langsung ke lapisan masyarakat untuk membaur dan merasakan apa yang masyarakat rasakan setiap harinya. Dengan hal ini, mahasiswa memenuhi salah satu poin dari Tri Dharma Perguruan Tinggi mengenai Pengabdian Masyarakat.

Sejauh ini pandemi virus COVID-19 telah mempengaruhi banyak sektor di berbagai lini kehidupan masyarakat. Selain kesehatan dan ekonomi, sektor pendidikan juga sangat dipengaruhi oleh pandemi ini, semua perguruan tinggi melakukan pembelajaran jarak jauh, meskipun tidak semua mahasiswa memiliki kemampuan untuk melakukannya. Mata kuliah yang mengharuskan pertemuan pun seperti praktek dan KKN juga menjadi terhambat. Meski begitu, manusia sudah selayaknya beradaptasi dengan perubahan. Oleh karenanya, mahasiswa juga harus beradaptasi dan melanjutkan kewajibannya untuk mengabdi kepada masyarakat walaupun muncul berbagai rintangan-rintangan seperti pandemi ini. Kami pun mengubah beberapa konsep program kerja dengan memanfaatkan teknologi agar tetap dapat melaksanakannya.

Dalam program kerja yang kami buat, kami fokus dalam bidang kesehatan dengan cara edukasi dan juga memberi bantuan langsung, karena walaupun pandemi di Indonesia sudah berjalan lebih dari tiga bulan, masih ada masyarakat yang belum memahami sepenuhnya tentang pandemi ini dan masih ada masyarakat yang masih membutuhkan bantuan. Dalam KKN ini kami menyasar masyarakat umum di seluruh Indonesia secara online dalam program edukasi dan menyasar pada masyarakat Jakarta Utara secara offline atau turun langsung yaitu menyasar masyarakat umum yang berada di daerah sungai bambu kecamatan tanjung priok untuk pembagian bantuan langsung. Kami berharap dengan edukasi dan bantuan langsung yang kami berikan akan meningkatkan kesadaran masyarakat dan juga kepeduliannya terhadap virus COVID-19 agar pandemi ini cepat selesai dan semua dapat kembali normal.

Dalam kegiatan kuliah kerja nyata, kami melakukan tiga kegiatan yang bersangkutan dengan audiens atau masyarakat. Kegiatan pertama adalah seminar online dengan topik "new normal". Seminar online tersebut diselenggarakan pada platform Zoom dan diikitu oleh lebih dari 50 pendaftar. Tujuan dari seminar online yang kami selenggarakan dengan topik "new normal" adalah agar masyarakat dapat mengetahui lebih detail bagaimana dan apa saja aturan-aturan yang ada pada kebijakan new normal serta bisa mempersiapkan diri untuk menghadapi kebijakan tersebut dan tidak salah memahami tentang new normal. Dalam seminar online hari kedua mahasiswa KKN memberikan pengetahuan dengan topik "menjaga imunitas tubuh dan kebersihan gigi" dalam seminar tersebut dijelaskan bagaimana langkah-langkah yang perlu dilakukan untuk menjaga 
imunitas tubuh terutama pada saat pandemi COVID-19 saat ini, diberikan juga pengetahuan mengenai cara merawat kebersihan gigi dan mulut. Tujuan dilakukannya seminar online dengan topik tersebut adalah agar masyarakat dapat memahami bahwa menjaga imunitas tubuh dan kebersihan gigi sangatlah penting terutama pada masa pandemi sekarang dan bagaimana cara-cara yang dapat dilakukan agar imunitas tubuh dan kebersihan gigi terjaga sehingga dapat terciptanya tubuh yang sehat. Pada akhir seminar online yang diselenggarakan panitia menayangkan vidio tentang panduan cuci tangan yang benar dan cara mencuci gigi yang benar.

Kegiatan lain yang dilakukan yaitu menyalurkan bantuan berupa masker dan handsanitizer kepada para pedagang kaki lima yang tidak menggunakan masker. Pembagian tersebut dilaksanakan pada zona hijau dengan target orang-orang yang kurang peduli dengan kesehatannya sendiri dan banyak ditemukan pada pedagang kaki lima. Tujuan dari kegiatan pembagian masker dan handsanitizer adalah agar para pedagang kaki lima yang kurang perduli pada kesehatannya dapat tergugah hatinya dan mau memakai masker dan handsanitizer saat melakukan aktivitas diluar rumah seperti bekerja. Harapan mahasiswa KKN kelompok 230 Jakarta adalah pada kegiatan kuliah kerja nyata kali ini walaupun ditengah pandemi COVID-19 sebisa mungkin mahasiswa tetap bisa memberikan manfaat bagi masyarakat khususnya masyarakat di Jakarta yaitu pedagang kaki lima, sehingga apa yang menjadi kewajiban mahasiswa dalam bidang pengabdian masyarakat dapat dilaksanakan dengan baik.

\section{METODE PENGABDIAN MASYARAKAT}

Kegiatan Pengabdian Masyarakat oleh kelompok 230 KKN 62 Universitas Airlangga Surabaya dilaksanakan pada tanggal 29 juni hingga 20 juli 2020 yang bertempat di Sungai Bambu, Kecamatan Tanjung Priok, Jakarta Utara. Program yang dilaksanakan terdiri dari beberapa bidang garap diantaranya bidang kesehatan berupa poster mengenai "Menjalani Fase New Normal saat Pandemi Covid-19", video cuci tangan yang benar sesuai anjuran World Health Organization (WHO), poster tentang “ Menjaga Imunitas Tubuh", poster mengenai "Kesehatan Gigi", video mengenai cara menyikat gigi yang baik, webinar mengenai "New Normal", webinar mengenai "Menjaga Imunitas Tubuh dan Kebersihan Gigi”. Program lainnya dengan bidang pendidikan yaitu your daily vocabulary serta bidang sosial yaitu pembagian masker dan handsanitizer.

Sosialisasi mengenai new normal merupakan acara yang diselenggarakan untuk memberikan informasi seputar Covid-19 serta persiapan diri dalam menghadapi keadaan new normal yang telah diterapkan oleh pemerintah. Sosialisasi new normal ini juga bertujuan untuk mengedukasi warga agar lebih memahami new normal serta protokol kesehatan yang perlu dipersiapkan selama berlangsungnya penerapan new normal. Hal ini kami lakukan dengan cara menyebarkan poster mengenai "Menjalani Fase New Normal saat Pandemi Covid-19" dan video cara mencuci tangan sesuai anjuran World Health Organization (WHO), serta melakukan kegiatan webinar mengenai new normal dan penerapan protokol kesehatan yang baik dan benar. Kegiatan sosialisasi webinar ini kami lakukan secara daring dan terbuka untuk masyarakat umum melalui aplikasi zoom agar kami dapat berinteraksi dengan masyarakat walaupun tanpa kontak fisik langsung. Sasaran yang dituju oleh kami adalah dari kalangan anak-anak hingga orang tua, hal ini bertujuan agar mereka mengetahui protokol kesehatan sesuai dengan anjuran pemerintah dan dapat menerapkannya dikehidupan sehari-hari. 
Sosialisasi mengenai new normal ini juga didukung dengan pembagian masker dan handsanitizer pada warga di Sungai Bambu, Kecamatan Tanjung Priok, Jakarta Utara. Kegiatan penyuluhan masker dan handsanitizer ditujukan agar warga Sungai Bambu dapat mengetahui langkah-langkah penggunaan masker yang benar sesuai dengan protokol kesehatan yang dikeluarkan oleh World Health Organization (WHO) dan mendistribusikan masker ke warga Sungai Bambu yang memiliki rencana kegiatan di luar ruangan. Informasi tentang penggunaan masker diambil dari praktik- praktik di fasilitas pelayanan kesehatan. Kami juga menginformasikan cara menggunakan handsanitizer yang baik dan penyuluhan mengenai cuci tangan yang lebih efektif dibanding penggunaan handsanitizer.

Sosialisasi tentang menjaga imunitas tubuh dan edukasi cara menjaga kesehatan dan kebersihan gigi dilakukan secara daring menggunakan aplikasi instagram dan zoom. Kami menyebarkan poster tentang menjaga imunitas tubuh dan edukasi cara menjaga kesehatan dan kebersihan gigi beserta video cara menyikat gigi yang baik dan benar melalui instagram agar masyarakat lebih memperhatikan dan menjaga kesehatan tubuh di masa pandemi covid-19 ini. Kami juga melakukan webinar agar kami dapat berinteraksi langsung dengan masyarakat walaupun tanpa kontak fisik. Sosialisasi mengenai menjaga imunitas tubuh dipresentasikan oleh salah satu anggota kami dengan menampilkan poster dan ppt serta memberi informasi mengenai makanan yang baik dikonsumsi pada masa pandemi covid-19. Pada webinar edukasi cara menjaga kesehatan dan kebersihan gigi dilakukan dengan memberikan penyuluhan menggunakan media flipchart dan phantom gigi. Flipchart berisikan materi singkat dengan animasi mengenai informasi kesehatan gigi sedangkan phantom gigi digunakan untuk memudahkan demonstrasi cara menggosok gigi yang baik serta menarik minat peserta webinar.

Pada program bidang pendidikan terdapat program dengan tema "Your Daily Vocabulary" yang bertujuan guna meningkatkan pengetahuan masyarakat mengenai kosa kata baru yang jarang dipakai secara umum sehingga dapat digunakan dikehidupan sehari-hari dan meningkatkan kemampuan berbahasa inggris masyarakat. Pada program ini kami membuat poster yang mudah dimengerti agar dapat menarik minat masayarakat untuk belajar bahasa inggris, poster ini di sebarkan melalui Instagram kami.

Sasaran program kegiatan yang dituju yaitu seluruh warga Sungai Bambu, Kecamatan Tanjung Priok, Jakarta Utara yang mana dapat dipaparkan sebagai berikut; 1) kegiatan sosialisasi new normal, penyuluhan dan pembagian masker dan handsanitizer dengan sasaran yang dituju yaitu seluruh warga, 2) kegiatan sosialisasi menjaag imunitas tubuh dan kesehatan gigi dengan sasaran yang dituju seluruh warga dan 4) kegiatan program pendidikan seperti Your Daily Vocabulary sasaran yang dituju adalah remaja dan orang tua. Program yang dibuat memiliki strategi pemberdayaan masyarakat, masyarakat dilibatkan baik secara langsung maupun tidak langsung. Strategi ini bertujuan untuk membuat masyarakat lebih mandiri dan meningkatkan kemampuan dalam memelihara dan meningkatkan hidup sehat dan produktivitas mereka sendiri di tengah masa pandemi dan masa transisi new normal ini.

\section{HASIL DAN PEMBAHASAN}

Kegiatan pengabdian masyarakat berupa penyuluhan dan sosialisasi tentang Adaptasi Kebiasaan Baru (AKB) dilaksanakan via daring dengan menggunakan 
aplikasi Zoom dan dilaksanakan dua kali, yaitu pada hari Selasa, 14 Juli 2020 dengan mengangkat topik "New Normal" dan pada hari Kamis, 16 Juli 2020 dengan mengangkat tema "Menjaga Imunitas Tubuh dan Kesehatan Gigi". Jumlah Peserta pada webinar pertama sebanyak 44 orang, dan jumlah webinar kedua sebanyak 44 orang. Peserta webinar merupakan peserta umum yang terdiri dari siswa sekolah, mahasiswa, orang tua dan akademisi.

Kegiatan webinar diisi dengan pembukaan oleh mc dan moderator, dilanjut sambutan dari Bu Zakiya selaku dosen pembimbing DP2D, lalu pemberian materi dari tim KKN 62 Unair kelompok 230, dan terakhir sesi tanya jawab. Pada materi pertama yaitu "New Normal", materi berisikan presentasi mengenai situasi New Normal saat pandemi. Materi dimulai dari pendahuluan tentang Covid-19 di Indonesia, lalu kondisi sebelum dan sesudah Penerapan Sosial Berskala Besar (PSBB), kegiatan dan situasi New Normal, dan ditutup dengan video cara mencuci tangan yang baik dan benar. Pada materi kedua yaitu "Immunitas Tubuh dan Kesehatan Gigi" menjelaskan tentang pendahuluan system imun, bagaimana Covid-19 dapat menginfeksi manusia, cara meningkatkan system imun, pendahuluan tentang gizi, penjelasan tentang Angka Kecukupan Gizi (AKG), Tabel Nilai Gizi, Indeks Massa Tubuh, lalu ikan dan olahannya. Materi ditutup dengan penjelasan tentang bagaimana cara menjaga dan meningkatkan Kesehatan gigi, dan juga video bagaimana cara menyikat gigi yang benar. Setelah mengikuti kegiatan webinar 1 dan 2, para peserta dibagikan kuisoner berupa google form untuk mengetahui hasil webinar terhadap cara pandang dan perilaku peserta.

Data kuisioner disajikan di diagram 1 dan diagram 2. Diagram 1 adalah data tentang bagaimana tingkat pengetahuan responden terhadap adaptasi kebiasaan baru. Sebesar $50 \%$ responden setuju, $45.8 \%$ responden sangat setuju, dan $4.2 \%$ responden tidak setuju. Diagram 2 adalah data tentang bagaimana pendapat responden tentang pengaplikasian adaptasi kebiasaan baru di kehidupan sehari-hari. Sebesar 50\% responden setuju, $45.8 \%$ responden sangat setuju, dan $4.2 \%$ responden tidak setuju. Dari hasil tersebut, dapat diketahui bahwa kegiatan webinar yang dilaksanakan dengan materi "New Normal" dan "Menjaga Imunitas dan Kesehatan Gigi" memiliki pengaruh terhadap para peserta dalam Adaptasi Kebiasaan Baru (AKB) ditengah pandemic Covid-19.

Diagram 1. Data Responden Tentang Pengetahuan Adaptasi Baru

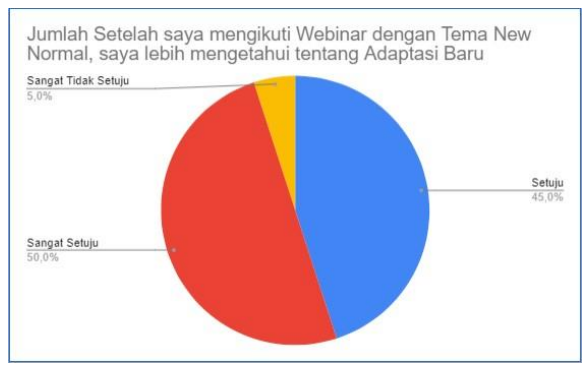

Diagram 2. Data Responden Tentang Pengaplikasian Dalam Kehidupan Sehari-hari

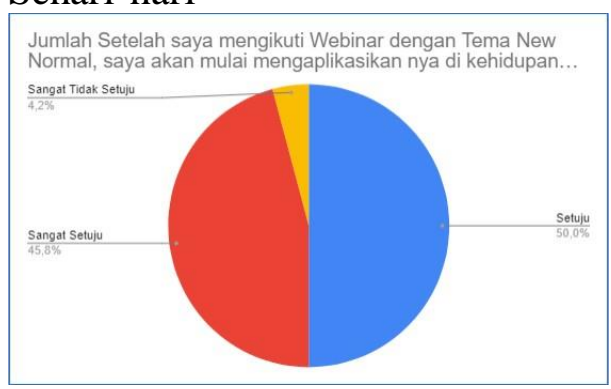

Kegiatan pengabdian masyarakat yang lain berupa pembagian masker dan hand sanitizer kepada warga di daerah Tanjung Priok, Jakarta Utara. Ada 100 masker dan hand sanitizer yang dibagikan kepada warga di daerah Tanjung Priok. Pembagian masker dan hand sanitizer dilakukan secara langsung, yaitu menyusuri jalanan dan 
membagikan kepada warga disana. Warga yang mendapat pembagian masker adalah pedagang kaki lima, ojek online, dan tukang parkir. Selain pembagian masker dan hand sanitizer, tim KKN 62 Unair Kelompok 230 juga mengingatkan pentingnya memakai masker dan menerapkan protocol Kesehatan sebagai Adaptasi Kebiasaan Baru (ABK) pada warga.

Coronavirus adalah virus RNA dengan ukuran partikel 120-160 nm. Penyebaran virus Covid-19 dari manusia ke manusia menjadi sumber transmisi utama. Transmisi Covid19 terjadi melalui droplet yang keluar saat batuk atau bersin. Selain itu, telah diteliti bahwa Covid-19 dapat viabel pada aerosol selama setidaknya 3 jam. Covid-19 menginfeksi sel-sel pada saluran napas yang melapisi alveoli, lali akan berikatan dengan reseptor-reseptor dan membuat jalan masuk ke dalam sel. (Susilo, 2020).

Virus Covid-19 merupakan sebuah pandemic yang menimbulkan banyak dampak negatif kepada seluruh lapisan masyarakat. Seiring perkembanga pemerintah dalam menghadapi pandemi, maka pemerintah menerapkan perilaku "New Normal" atau Adaptasi Kebiasaan Baru (AKB). Adaptasi Kebiasaan Baru adalah tata laksana kebiasaan masyarakat selama pandemic Covid-19, agar tetap bisa melakukan aktivitas dengan tetap melaksanakan protokol Kesehatan. Adaptasi Kebiasaan Baru (AKB) meliputi jaga jarak, cuci tangan dengan sabun, menghindari kontak fisik dan menjaga jarak (Kemenkes, 2020). Oleh karena itu, pemahaman masyarakat tentang Adaptasi Kebiasaan Baru haruslah menyeluruh, agar dapat berjalan sebagaimana mestinya.

Salah satu cara untuk terhindar dari virus covid-19 adalah dengan menjaga imunitas tubuh. Sistem imun (immune system) atau sistem kekebalan tubuh adalah kemampuan tubuh untuk melawan organisme patogen. Jika sistem kekebalan melemah, kemampuan untuk melindungi tubuh berkurang, sehingga patogen, termasuk virus dapat tumbuh dan berkembang dalam tubuh. Salah satu cara untuk menjaga imuntias tubuh adalah dengan mengonsumsi makanan bergizi, salah satunya yang mengandung zat gizi mikronutrien seperti vitamin dan mineral. (Siswanto, 2013). Mineral dan vitamin dibutuhkan dalam jumlah kecil dalam tubuh tapi sangat penting untuk proses dan reaksi metabolic dan pemeliharaan Kesehatan. Vitamin juga berperan seabgai koenzim yang bertanggung jawab terhadap reaksi kimia. Sebagian besar vitamin dan seluruh mineral tidak dapat disintesa oleh tubuh sehingga harus diperoleh dari makanan terutama buah, sayur dan pangan hewani. Untuk memenuhi kebutuhan vitamin dan mineral ini maka diperlukan konsumsi makanan yang seimbang dan beragam. Selain membantu proses metabolism zat gizi, vitamin dan mineral juga dapat sebagai antioksidan yang sangat mempengaruhi kualitas hidup manusia. Antioksidan adalah zat yang secara signifikan dapat menurunkan efek negatif akibat spesies yang reaktif seperti oksigen reaktif dan nitrogen reaktif yang terbentuk dalam tubuh. Beberapa vitamin dan mineral yang mempunyai peran sebagai antioksidan, diantaranya adalah vitamin $\mathrm{A}$, vitamin $\mathrm{E}$, vitamin $\mathrm{C}$, selenium, zat besi dan zinc. (Siswanto, 2013).

Selain mengonsumsi makanan bergizi yang mengandung vitamin dan mineral, cara untuk menambah imunitas dan terhindari dari Covid-19 adalah dengan memperbaiki kualitas tidur, berhenti mengonsumsi alcohol dan berhenti merokok. Kurang tidur juga dapat berdampak terhadap imunitas. Gangguan tidur berhubungan dengan peningkatan kerentanan terhadap infeksi. Merokok menurunkan fungsi proteksi epitel saluran napas, 
makrofag alveolus, sel dendritik, sel NK, dan sistem imun adaptif. Merokok juga dapat meningkatkan virulensi mikroba dan resistensi antibiotika. (Susilo, 2020).

\section{PENUTUP \\ Simpulan}

Dengan diadakanya 2 sesi kegiatan seminar online secara prinsip bermanfaat bagi para peserta dimana dapat dilihat dalam diagram 1 yang menjelaskan data tentang bagaimana tingkat pengetahuan responden terhadap adaptasi kebiasaan baru. Sebesar $50 \%$ responden setuju, $45.8 \%$ responden sangat setuju,. Lalu pada diagram 2 yang menjelaskan data tentang bagaimana pendapat responden tentang pengaplikasian adaptasi kebiasaan baru di kehidupan sehari-hari. Sebesar 50\% responden setuju, $45.8 \%$ responden sangat setuju. Dari hasil tersebut, dapat diketahui bahwa kegiatan webinar yang dilaksanakan dengan materi "New Normal" dan "Menjaga Imunitas dan Kesehatan Gigi” memiliki pengaruh terhadap para peserta dalam Adaptasi Kebiasaan Baru (AKB) ditengah pandemi Covid-19.

\section{Saran}

Dalam pelaksanaan pengabdian masyarakat yang kelompok kami lakukan dengan mengadakan seminar online dengan materi "New Normal" dan "Menjaga Imunitas dan Kesehatan Gigi" dapat didapatkan bahwa perlu didakan lebih banyak lagi sosialisasi tentang bagaimana cara beradaptasi pada kebijakan new normal dan meningkatkan imunitas tubuh selama pandemi covid-19. Karena dengan diadakan sosialisasi yang lebih banyak, maka lebih banyak lagi masyrakat yang akan siap dan paham cara menghadapi kebijakan "new normal" dan menjaga imunitas tubuh selama pandemic Covid-19.

\section{DAFTAR PUSTAKA}

Kementerian Kesehatan Republik Indonesia. 2012. Materi Medsos Adaptasi Kebiasaan Baru (PDF). Direktorat

Promosi Kesehatan dan Pemberdayaan Masyarakat, Jakarta.

Siswanto, B. and Ernawati, F., 2013. Peran beberapa zat gizi mikro dalam sistem imunitas. Gizi Indon, 36(1), pp.57-

Susilo, A., Rumende, C.M., Pitoyo, C.W., Santoso, W.D., Yulianti, M., Herikurniawan, H., Sinto, R., Singh, G., Nainggolan, L., Nelwan, E.J. and Chen, L.K., 2020. Coronavirus Disease 2019: Tinjauan Literatur Terkini. Jurnal Penyakit Dalam Indonesia, 7(1), pp.45-67. 